\title{
INTERRELATIONSHIPS AMONG CRITICAL FACTORS OF WORK FLOW RELIABILITY IN LEAN CONSTRUCTION
}

\author{
Lianying ZHANG, Xi CHEN, Yongqing SUO \\ College of Management and Economics, Tianjin University, 92 Weijin Road, \\ Nankai District, 300072, Tianjin, P.R. China
}

Received 27 Oct 2015; accepted 21 Jun 2016

\begin{abstract}
Work flow in lean construction has a significant influence on project performance. Uncertain work flow will lead to waste and reduce labor productivity. Reliable work flow will contribute to improving project performance. We found twenty variables affecting work flow reliability by literature review. In order to identify critical factors of work flow reliability and explore interrelationships among them, we designed a questionnaire to collect data, applied factor analysis to identifying critical factors, and put forward hypotheses on the basis of previous research and applied structural equation model (SEM) to exploring interrelationships among the critical factors of work flow. Final model confirmed nine hypotheses and denied three hypotheses. Besides, this paper discovered other interrelationship among the critical factors except for the hypotheses. The result of this research will help project managers understand work flow easily and take effective measures to improve work flow reliability, which will contribute to implement lean construction successfully.
\end{abstract}

Keywords: lean construction, reliability, construction management, work flow, critical factors.

\section{Introduction}

Since Lauris Koskela put forward lean construction in 1993, many scholars have done a lot of research to study lean construction. Lean construction came from lean manufacturing which came from Toyota Production System (TPS). Manufacturing plants are different from construction sites. Besides, their end products are different. In manufacturing, the products generally can be moved. The products of construction, on the other hand, are still. In addition, differences between construction and manufacturing include three features: on-site production, oneof-a-kind projects, and complexity (Salem et al. 2006). To some extent, uncertainty of construction process is the result of the effect of three features above (Salem et al. 2006). Hence, we cannot apply lean manufacturing on construction management directly. Lean manufacturing is the "inspiration" of lean construction on the contrary (Becker et al. 2011). According to the research above, lean construction refers to the application of the inherent lean manufacturing concepts, principles, and tools on construction management (Thomas et al. 2003). Hence, lean construction focus on reducing the construction waste, increasing the value of products and continuous improvement.

Work flow is an important aspect of lean construction. Reliable work flow could reduce construction waste, improve labor productivity and project performance. Therefore, we conducted a research to identify critical factors of work flow reliability and explore interrelationships among them.

\section{Literature review}

In lean construction, definition of work flow was the movement of materials, information, labor, equipment etc. during the construction process (Thomas et al. 2003). In construction, most of the end products keep stationary, whereas staffs, sometimes even equipment, move from one place to another to complete work. This feature of construction makes it different from manufacturing and draws much attention to the work flow in lean construction. It is necessary to study the impact of work flow on construction performance and how the work flow affects the construction work. Therefore, Tommelein et al. (1999) did a research to study the impact of work flow variability on succeeding trades performance and project completion, which was well simulated by the Parade Game. The game showed that experienced and successful project managers would endeavor to keep reliable work flow and it was possible to reduce waste and shorten project duration through reducing the variability in work flow. Besides, this study discovered two kinds of waste 
due to unreliable work flow: production stations couldn't realize their full production capacity and intermediate buffers were larger when high variability happened. Work flow variability could lead to uncertainty conditions, fluctuant process, unstable objectives, and make it unclear to achieve them (Thomas et al. 2002). However, the causes of work flow variability were not clearly examined in their study. According to Koskela, a stable work flow depended on construction preconditions such as resources and prerequisites. In order to detail how variation of normal work flow affected construction labor efficiency, Thomas (2000) did a research aiming at describing how the amount of work available for the contractor to performed when the schedule was accelerated was related to labor efficiency. This study put forward an assumption that labor inefficiencies are related to interruptions in the normal flow of work available for the contractor to perform. On one hand, labors would be inefficient when too many tasks were assigned especially in a situation that schedule was accelerated. On the other hand, inefficiencies also occurred when less work was available. Hence, it is necessary to assign appropriate work to labors considering their actual capacity. To some extent, improving flow reliability means to make sure that adequate resources are available at the right time, especially the labor resource. Thomas et al. (2002) in another empirical study, took an research to study the relationship between construction output variability and labor performance, aiming at explaining the influence of lean initiative on project performance. The research finally discovered that the variability in daily labor productivity was highly correlated with project performance. This study drew a conclusion that it was necessary to reduce variability caused by unreliable flows and manage the remaining system variability by using effective labor management strategies. In addition, H. Randolph Thomas et al. (2003) test whether improving flow reliability improved construction productivity. They finally concluded that the more reliability work flow was, the more productivity construction had. Another important conclusion they got was that labor flow was an important component of lean flow. It accounted for $58 \%$ of the total flow losses. But relationships between work flow variation and labor productivity had not been well researched. Therefore, Min Liu et al. did a case study to find the relationship between work flow variation and labor productivity. The conclusion of this study was that work flow reliability and labor productivity were significantly correlated, and Last Planner System (LPS) could reduce work flow variation, thereby helping improve labor productivity (Liu et al. 2011). Mitropoulos and Nichita (2010) did a case study to analyze the performance problems on a large residential project with significant labor constraints. In this study, the work flow analysis discovered that quality problems and labor shortage could lead to extensive disruptions. Finally, this case study illustrated how the combination of high resource utilization and unreliable work flow led to de- lays. Fewer delays would occur in a construction process with fewer disruptions and less variability under high capacity utilization. As Koskela inferred in 2000, productivity and duration could be improved at the same time through improving work flow reliability. Therefore, under the circumstance of labor shortage, it was important to take advantage of available labor by keeping reliable work flow. However, specific labor factors affecting labor flow and work flow are not clearly understood. Therefore, Lee et al. (2004) focused on the causes of work flow variability, especially on factors related to labor resources. They proposed three hypotheses: labor resource stability would affect workflow, worker loyalty would affect workflow, and worker loyalty would affect labor resource stability. In their study, they finally concluded that (1) worker loyalty had direct and indirect influences (through labor resource stability) on work flow, (2) the strength of direct effect and indirect effect were almost equal, (3) worker loyalty accounted for nearly $55 \%$ of the variation in labor resource stability, and (4) worker loyalty and labor resource stability accounted for nearly $45 \%$ of the total variation in work flow. Therefore, in order to manage work flow effectively, it was necessary to monitor worker attendance ratio and worker change ratio during the construction process. Besides, it was important to implement appropriate labor management strategies to improve both worker loyalty and labor resource stability. However, only about $45 \%$ of the total variation in workflow was accounted for. The research of remaining 55\% was still not enough.

Except for the research on the labor's effect, Tribelsky and Sacks (2010) did a research on the information's effect on work flow. In construction, the information needs come from multiple sources and vary daily (Thomas et al. 2003). Inefficient information flow could lead to much waste in construction. However the lack of methods of measuring the volume, rate and effectiveness of information flow hinder the research. As a result, they proposed a method to measure the flow of information in the process of detailed design where construction documents are prepared (Tribelsky, Sacks 2010). But this study didn't find how the information flow affects construction work and to what extent information flow are important to workflow. Employees should particularly experience flow when their work match their professional skills (Bakker 2008). As a result, Bakker (2008) tried to develop a reliable and valid instrument to measure flow-experience at work. In Bakker's point, the most prominent definitions of flow had three elements in common - absorption (i.e., the total immersion in an activity), enjoyment, and intrinsic motivation. The research found that the job characteristics explained $18.7 \%$ of the variance in absorption, $28.3 \%$ of the variance in work enjoyment, and $20.9 \%$ of the variance in intrinsic motivation. However, the final result inferred that several other factors affecting flow need to be studied, like employees' personal resources. Chen et al. (2008) advanced a new 
concept - FlowMIS. They did a research on highway construction management information systems based on work flow. But this study was just the actual application of work flow in construction; it didn't study the effect of information on work flow. A construction project requires a lot of construction equipment and the equipment is mobile and shared by multiple staffs, which means that an inefficient traffic flow could reduce the overall efficiency of construction work (Kim K. J., Kim, K. 2010). Therefore, K. J. Kim and K. Kim (2010) conducted a research to evaluate the effect of traffic flow on the efficiency of construction operations. Finally, the research found that the flow of construction equipment had a significant effect on the efficiency of construction operations. In the sample project in this study, additional equipment could decrease $48.8 \%$ of truck speed and $61.6 \%$ of work efficiency. This study inferred that equipment also had an effect on the reliability of work flow. Previous research has shown the cause-and-effect between workflow management and productivity, but few of them has shown the importance of workflow management and the factors that cause disruptions in equipment-intensive operations. As a result, Choi and Minchin (2006) put a hypothesis in their research that controlling uncertainty and variability was a significant factor in the effective management of production for equipment-intensive operations. Besides, this research also focused on validating the influence of work flow management in equipment-intensive tasks by conducting case studies for highway pavement operations. Finally, this case study found that the loss of work hours caused by poor management ranged from $40 \%$ to $62 \%$ of the total inefficient work hours on the four projects used in the research. Out-of-sequence work and deficiencies in prerequisite work contributed to poor management to some extent.

Since Koskela put forward "transformation-flowvalue" (TFV), many scholars had done research to study how to apply the manufacture approaches to construction process. In lean manufacturing, visualization of manufacturing process could help the workers understand the state of assembly line in time. They could take measures to solve the problems in advance. Besides, visualization could also reduce the chance of making mistakes. However, the physical environments and the contracting relationships typical of construction projects made it inappropriate apply lean techniques directly on construction (Sacks et al. 2009). Therefore, Sacks et al. (2009) did a research to study visualization of work flow in construction. Visualization could make workers understand and response to problems rapidly. Besides, visualization help to reduce uncertainties and misconceptions, which could improve work flow reliability and reduce waste.

In construction, variability had an influence on production rates, labor productivity, schedule control, cost control, etc. (González et al. 2010). González et al. (2010) proposed a decision-making tool based on lean principles, called the reliable commitment model (RCM), which used statistical models to make commitment planning at an operational level more reliable. Finally, the RCM showed that it could improve planning reliability and project performance through case study.

According to the preview research, most research just studied the relationship between single factor and workflow reliability. The critical factors of workflow reliability are not clearly enough yet. The research of interrelationships among the critical factors and how they affect work flow reliability is also not enough. Therefore, this paper focuses on the critical factors affecting workflow reliability and the interrelationships among them.

\section{Methodology}

In order to identify the critical factors of work flow reliability, we adopted a questionnaire for data collection in this research. In order to collect the relatively accurate data, we conducted a pilot study to find out inappropriateness of the questionnaire and correct them. Each of respondents was asked to complete the questionnaire to see whether they had any doubt about the questionnaire or whether they could finish the questionnaire without any guidance. Then making an interview with the respondents according to the result to find out whether there were any factors that were not considered before. After correcting the questionnaire, we used the final version of the questionnaire in the formal survey. We conducted the survey through two ways, paper questionnaire and online questionnaire. Respondents consisted of project managers, foremen, and workers.

After collecting data, we applied factor analysis to identifying the critical factors of work flow reliability through SPSS 18.0. Factor analysis is a common method to identify the critical factors. Wambeke et al. (2011) applied factor analysis to identifying critical factors that affected task starting times and duration in construction project. Chen and Kao (2010) applied factor analysis to identifying success variables in construction partnerships and the study finally found four success variables, which are collaborative team culture, long-term quality perspective, consistent objectives and resource sharing. In order to understand the impact of key stakeholders (clients, consultants, and contractors) on cost performance in construction projects, Doloi (2013) used confirmatory factor analysis in the survey to identify the critical factors on cost performance. It finally showed eight key factors having influence on cost performance including accurate project planning and monitoring, design efficiency, effective site management, communication, contactors' efficiency, project characteristics, due diligence, market competition. Hon et al. (2013) also applied exploratory factor analysis to identifying safety climate factors in the RMAA (repair, maintenance, minor alteration, and addition) sector. Three factors were identified: management commitment to occupational health and safety (OHS) and employee involvement, application of safety rules and work practices, and responsibility for health and safety. Then they 
conducted confirmatory factor analysis and the result showed satisfactory goodness of fit, reliability, and validity. Besides, Ye et al. (2013) found seven critical factors in compiling tender prices for China's public work, including construction cost, contractor heterogeneity, payment arrangement, potential competitors, clients' requirements/ expectations, market condition, and third-party stakeholders. Although many scholars applied factor analysis to identifying key factors in construction project, there is not enough research applying factor analysis to identifying critical factors of work flow reliability in construction. Therefore, this research will apply factor analysis to identifying critical factors of work flow reliability in construction.

On the basis of factor analysis, this research applied SEM to study the interrelationships among these critical factors and their effect path to work flow reliability through AMOS 17.0. SEM has been used in construction to find out the interrelationships among the factors that affect project performance. Chen et al. (2012a) used SEM to explore the relationship among the success variables of construction partnering. The result showed that the correlation between collaborative team culture and consistent objectives was the highest, and the correlation between collaborative team culture and long-term quality perspective was the lowest. Cheung and Chow (2011) applied SEM to find out the relationship between withdrawal in construction project dispute negotiation and three behavioral primers (motivation, cognition, and personality). The research showed that cognition had the strongest influence on withdrawal in construction project dispute negotiation, and emotion under the cognition made the greatest contribution to the withdrawal in construction project dispute negotiation. Chen et al. (2012b) conducted a research to explore the interrelationships among critical success factors of construction projects based on the SEM. This research finally found many underlying relationships among the critical success factors, which help the project managers to take effective measures to make reasonable resource allocations. Zhang and Ng (2013) applied SEM to study factors affecting individual knowledge-sharing behavior in construction teams in an integrative perspective based on theory of planned behaviour (Zhang, Ng 2013). The research indicated that perceived behavior control and attitude mainly affect professionals' knowledge-sharing intention. Li et al. (2013) conducted a research to study factors that affected transaction costs in construction projects with applying SEM. It was found that uncertainty in the transaction environment mainly affected transaction cost among the four main factors, uncertainty in the transaction environment, predictability of the owner's behavior, predictability of the contractor's behavior, and project management efficiency. Although many scholars applied SEM to understanding the relationships among factors affecting construction project, there is not enough research applying SEM to studying interrelationship among critical factors of work flow reli- ability in construction. Therefore, this research will use SEM to finding out the interrelationship among the critical factors and their direct and indirect influence on work flow reliability.

\section{Survey process}

According to the literature review, variable factors of work flow reliability are sorted out in Table 1.

We designed a questionnaire on the basis of these factors collected from literatures. The questionnaire consisted of two parts. The first part of the questionnaire collected the basic background information of the respondents, including their gender, education degree and position in their work. The second part of the questionnaire collected the basic data of the variable factors' effect on work flow reliability. The questions in second part were designed on the basis of Likert scale. Responds were asked to answer the effect of each factors on work flow reliability according to their actual work experience. There were five options, which were strongly disagree, disagree, neither agree nor disagree, agree and strongly agree or strongly unimportant, unimportant, neither important nor unimportant, important and strongly important. The answer that was strongly disagree or strongly unimportant got 1 point and next rank got 2 points. The answer that was strongly agree or strongly important got 5 points. It took about 20 minutes to finish the questionnaire.

Firstly, we conducted the pilot study in November 2013. 20 respondents including 3 project managers, 5 foremen and 12 workers were involved in the pilot study. We asked each of them to complete the questionnaire to see whether they had any doubt about the questionnaire or whether they could finish the questionnaire without any guidance. The result of pilot study showed that there existed some questions difficult for respondents to understand. Only under the guidance could they answer the questions. Then we made an interview with the respondents according to the result to find out whether there were any factors that were not considered before. Five questions were asked in the interview:

What are the accidents that would disturb the work and make it impossible to complete the work in in time according to your work experience?

- Among the accidents which occurred in high frequency?

- How do the accidents that happens in high frequency disturb the work?

- Please rank these accidents according to their extent of influence from high to low;

- Do you have any suggestions to reduce their influence on work?

According to the pilot survey and interview we corrected the questionnaire, and made a final version for the formal survey. Two factors, shortage of labor resource and predictable work flow were deleted. According to the respondents' experience, projects were often not enough 
Table 1. Summary of the variables of work flow reliability

\begin{tabular}{|c|c|c|}
\hline $\begin{array}{l}\text { Variables of work } \\
\text { flow reliability }\end{array}$ & Description & Author/reference \\
\hline Labor & $\begin{array}{l}\text { Variability of labor productivity had an influence on work flow. Poor } \\
\text { labor management led to the labor inefficiency which caused work flow } \\
\text { unreliable. Worker loyalty had a direct influence on work flow and indirect } \\
\text { influence through labor resource stability. Labor resource stability had a } \\
\text { direct influence on work flow. Labor shortage had an influence on work flow } \\
\text { reliability. }\end{array}$ & $\begin{array}{l}\text { Thomas et al. }(2002 \text {, } \\
\text { 2003); Lee } \text { et al. } \\
\text { (2004); } \\
\text { Liu et al. (2011); } \\
\text { Mitropoulos and } \\
\text { Nichita (2010) }\end{array}$ \\
\hline Information & $\begin{array}{l}\text { Slow and interrupted information flow could lead to significant waste. } \\
\text { Correct, complete, and timely information would improve work flow } \\
\text { reliability. }\end{array}$ & $\begin{array}{l}\text { Chen et al. }(2008) \text {; } \\
\text { Tribelsky and Sacks } \\
(2010) ; \text { Thomas } \text { et al. } \\
\text { (2002) }\end{array}$ \\
\hline Equipment & $\begin{array}{l}\text { Equipment flow had a significant influence on effectiveness of construction } \\
\text { process. Sharing of equipment and insufficient tools could be obstacles of } \\
\text { work flow reliability. }\end{array}$ & $\begin{array}{l}\text { K. J. Kim and K. Kim } \\
(2010) \text {; Thomas et al. } \\
(2002)\end{array}$ \\
\hline $\begin{array}{l}\text { Flexible capacity } \\
\text { strategies }\end{array}$ & Flexible capacity strategies could help manage work flow more effectively. & Thomas et al. (2002) \\
\hline $\begin{array}{l}\text { Flexible work } \\
\text { assignments }\end{array}$ & Flexible work assignments could reduce the variability in work flow. & Thomas et al. (2003) \\
\hline Amount of work & $\begin{array}{l}\text { Too much work or less work could lead to labor inefficiencies which would } \\
\text { cause work flow variability. }\end{array}$ & Thomas (2000) \\
\hline Work plans & Low reliability of work plans could lead to uncertainty of work flow. & $\begin{array}{l}\text { Mitropoulos and } \\
\text { Nichita (2010) }\end{array}$ \\
\hline Quality management & $\begin{array}{l}\text { Effective quality management could reduce delays, avoid rework and } \\
\text { improve work flow reliability. }\end{array}$ & $\begin{array}{l}\text { Mitropoulos and } \\
\text { Nichita (2010) }\end{array}$ \\
\hline $\begin{array}{l}\text { Job demands match } \\
\text { professional skills }\end{array}$ & $\begin{array}{l}\text { Work flow would be experienced when the employees' job demands matched } \\
\text { their professional skills. }\end{array}$ & Bakker (2008) \\
\hline Poor management & $\begin{array}{l}\text { Poor management could cause variable work flow. Out-of-sequence work and } \\
\text { deficiencies in prerequisite work could lead to poor management. }\end{array}$ & $\begin{array}{l}\text { Choi and Minchin } \\
(2006)\end{array}$ \\
\hline Work content & Work content could cause variable work flow & $\begin{array}{l}\text { Choi and Minchin } \\
\text { (2006) }\end{array}$ \\
\hline $\begin{array}{l}\text { Severe weather } \\
\text { conditions }\end{array}$ & Severe weather conditions could cause variable work flow. & $\begin{array}{l}\text { Choi and Minchin } \\
\text { (2006) }\end{array}$ \\
\hline Rework & $\begin{array}{l}\text { Rework affected information flow negatively and led to variability or work } \\
\text { flow disruption. }\end{array}$ & $\begin{array}{l}\text { Tribelsky and Sacks } \\
(2010) ; \text { Thomas } \\
(2000) ; \text { Thomas } \text { et al. } \\
(2002,2003)\end{array}$ \\
\hline $\begin{array}{l}\text { Visualization of } \\
\text { work flow }\end{array}$ & $\begin{array}{l}\text { Visualization of work flow could help workers response more rapidly and } \\
\text { reduce wasted and uncertainty. }\end{array}$ & Sacks et al. (2009) \\
\hline Planning Reliability & $\begin{array}{l}\text { Reliable work plans could develop a reliable work flow and improve project } \\
\text { performance. }\end{array}$ & González et al. (2010) \\
\hline $\begin{array}{l}\text { Adequate } \\
\text { prerequisite }\end{array}$ & Adequate prerequisite could reduce variability of work process. & Wambeke et al. (2011) \\
\hline Materials & Lack of construction materials could cause variation of construction process. & Enshassi et al. (2010) \\
\hline $\begin{array}{l}\text { Engineers' behavior } \\
\text { and specific } \\
\text { knowledge }\end{array}$ & $\begin{array}{l}\text { Lack of engineers' behavior and specific knowledge could cause variation of } \\
\text { construction process. }\end{array}$ & Enshassi et al. (2010) \\
\hline $\begin{array}{l}\text { Owner's intervention } \\
\text { and fund }\end{array}$ & $\begin{array}{l}\text { Lack of owner's intervention and fund could cause variation of construction } \\
\text { process. }\end{array}$ & Enshassi et al. (2010) \\
\hline $\begin{array}{l}\text { Collaboration of } \\
\text { each part in the } \\
\text { project }\end{array}$ & $\begin{array}{l}\text { Lack of collaboration of each part could cause variation of construction } \\
\text { process. }\end{array}$ & Enshassi et al. (2010) \\
\hline
\end{tabular}


instead of shortage of labor resource. As a result, they had little experience about the influence of labor resource shortage on work flow. Besides, predictable work flow also seldom arose in their actual work and they could not tell the influence of predictable work flow on work flow reliability. Because of the difficulty to understand visualization of work flow, we broke down it into two questions, transparent information and rapid transmission, and clear and transparent work process. Besides, we modified the expression of some questions to make it easier for respondents to understand. There were 19 factors involved in the final version of the questionnaire. Moreover, percentages of plan completed (PPC) and productivity of workers were two criterion measuring work flow reliability.

We conducted a formal study in November and December 2014 on four construction sites in Tianjin. Two ways, paper questionnaire and online questionnaire, were used in this survey. Respondents consisted of project managers, foremen, and workers. Finally, we collected 415 questionnaires, 213 paper questionnaires and 202 online questionnaires. Among the respondents, there were 14 project managers or once being a project manager, 23 foremen or having foreman experience, and 378 workers.

\section{Factor analysis}

In the factor analysis, Cronbach's Alpha value was 0.81, which indicated that the questionnaire was reliable. KMO value was 0.851 , indicated that it was appropriate to apply factor analysis in this research. The extraction method in this research was principal component analysis and the rotation method was Varimax with Kaiser Normalization. The overall rotated factor loadings and variance explained of variables affecting work flow reliability are showed in Table 2. Finally, 5 critical factors were extracted in this research which could explain $64.23 \%$ of the work flow reliability. According to the overall rotated factor loadings, 8 variables loaded on Factor 1, 5 variables loaded on Factor 2, 2 variables loaded on Factor 3, 2 variables loaded on Factor 4 and 2 variables loaded on Factor 5. Therefore, the five factors extracted were named support of each part in project, managerial level, labor resource, visualization of work flow, and rework and weather.

Support of each part in project refers to each part, including suppliers, engineers, the owners, collaborates to complete the task with high quality in time. Suppliers supplying material in time, engineers having necessary specific knowledge and reasonable action, owners having

Table 2. Overall rotated factor loadings of critical factors of work flow reliability

\begin{tabular}{|c|c|c|c|c|c|}
\hline & \multicolumn{5}{|c|}{ Factor Loading } \\
\hline & $\begin{array}{c}\text { Factor } 1 \\
\text { (Support of Each } \\
\text { Part in project) }\end{array}$ & $\begin{array}{c}\text { Factor } 2 \\
\text { (Managerial } \\
\text { Level) }\end{array}$ & $\begin{array}{c}\text { Factor } 3 \\
\text { (Labor } \\
\text { Resource) } \\
\end{array}$ & $\begin{array}{c}\text { Factor } 4 \\
\text { (Visualization } \\
\text { of Work Flow) } \\
\end{array}$ & $\begin{array}{c}\text { Factor } 5 \\
\text { (Rework and } \\
\text { Weather) } \\
\end{array}$ \\
\hline V1: Labor loyalty & & & .847 & & \\
\hline V2: Labor resource stability & & & .819 & & \\
\hline V3: Appropriate amount of work & & .465 & & & \\
\hline V4: Reliable planning & & .706 & & & \\
\hline V5: Reasonable task & & .749 & & & \\
\hline V6: Adequate prerequisite & & .808 & & & \\
\hline V7: Reasonable work sequence & & .760 & & & \\
\hline V8: Appropriate information transfer & .770 & & & & \\
\hline V9: Supplying materials in time & .802 & & & & \\
\hline V10: Engineer's action & .880 & & & & \\
\hline V11: Engineer's specific knowledge & .889 & & & & \\
\hline V12: Owner's intervention & .895 & & & & \\
\hline V13: Owner's fund & .891 & & & & \\
\hline V14: Collaboration of each part in the project & .834 & & & & \\
\hline V15: Amount of equipment & .663 & & & & \\
\hline $\begin{array}{l}\text { V16: Transparent information and rapid } \\
\text { transmission }\end{array}$ & & & & .825 & \\
\hline V17: Clear and transparent work process & & & & .795 & \\
\hline V18: Less rework & & & & & 689 \\
\hline V19: Good weather & & & & & .658 \\
\hline Variance Explained (\%) & 29.547 & 13.430 & 7.650 & 7.430 & 6.174 \\
\hline Cumulative (\%) & 29.547 & 42.977 & 50.627 & 58.056 & 64.230 \\
\hline
\end{tabular}


enough funds and reasonable intervention, appropriate information transfer, and enough equipment are involved in support of each part. Each part completing its own work in time will make it possible for the next step to start on time. As a result, work flow in the project will keep reliable, which will lead to a good performance. Managerial level means management of work, plan, task, prerequisite, and work sequence. Reasonable amount of work, reliable planning, reasonable task, adequate prerequisite work, and reasonable work sequence will make the work flow reliable. Labor resource involves labor loyalty and labor resource stability. Loyal labors and stable labor resource will reduce variation of work flow to some extent (Lee et al. 2004). Visualization of work flow can be considered as transparent information and rapid transmission, and clear and transparent work process. Transparent information and rapid transmission will reduce the possibility of misunderstanding information and information transmission time. Clear and transparent work process will let the workers know the current state and respond to the potential problem quickly. Rework will increase the waste, and ultimately result in increased costs. Rework also delays the next step, which finally will lead to an unreliable work flow. The influence of weather on work flow is obvious. Bad weather may disturb the plan.

\section{Structural equation model of critical factors of work flow reliability}

According to the result above, we put forward twelve hypotheses according to the past research, which is showed in Figure 1. The arrows represent the direct influence. Twelve hypotheses about the interrelationships among the critical factors of work flow reliability are as follows:

H1: Labor resource has a direct influence on work flow reliability;

$\mathrm{H} 2$ : Managerial level has a direct influence on work flow reliability;

H3: Support of each part in project has a direct influence on work flow reliability;

H4: Visualization of work flow has a direct influence on work flow reliability;

H5: Rework and weather have a direct influence on work flow reliability;

H6: Labor resource has a direct influence on rework;

H7: Managerial level has a direct influence on rework;

H8: Visualization of work flow has a direct influence on rework;

H9: Support of each part in project has a direct influence on rework;

H10: Managerial level has a direct influence on labor resource;

H11: Support of each part in project has a direct influence on managerial level;

H12: Support of each part in project has a direct influence on visualization of work flow.

Among the hypotheses above, although less rework and good weather were classified into one category, this

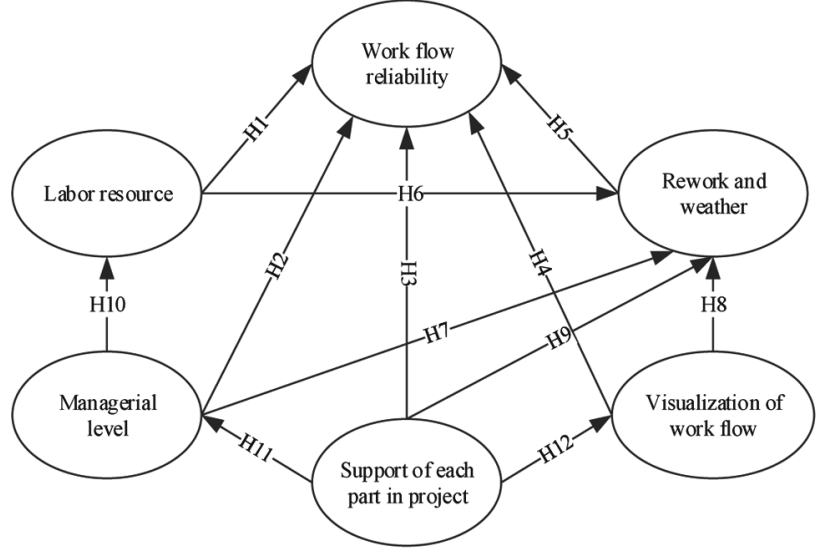

Fig. 1. Hypothesized interrelationships among the critical factors of work flow reliability

research just studied the effect of labor resource, managerial level, visualization of work flow, and support of each part in project on rework. The reason is that weather is natural environment that is not affected by labor, managerial, visualization, or support of each part in project.

In this study, the SEM consisted of a measurement component and a structural component. The measurement component was about exogenous variables measuring latent variables. The structural component was about the interrelationships among critical factors and work flow reliability. A basic framework was developed on the basis of past empirical findings and research results. Figure 2 shows the initial SEM of the interrelationship framework between work flow reliability and critical factors. In the initial SEM, there are five latent variables and twenty-one exogenous variables. Latent variables consist of labor resource, managerial level, support of each part in project, visualization of work flow, rework and weather, and work flow reliability. Each of labor resource, visualization of work flow, rework and weather, and work flow reliability has two exogenous variables. Managerial level has five exogenous variables. Support of each part in project has 8 exogenous variables.

Figure 3 shows the final SEM of the interrelationship framework between work flow reliability and critical factors. Revision was on the basis of past theories and findings. The standardized regression weights of final model are significant. All the standardized regression weights of measure component are larger than 0.71 , which means the indicator reliability of exogenous variables is good. Goodness of fit indices were used to assess the overall fitness of the SEM. Table 3 shows the goodness of fit indices of the final SEM framework.

In order to prove the validity of SEM application, the research then adopted the approach of nested model to analyze the adequacy and sensitivity of the theoretical model. Based on the theoretical model, we proposed 12 nested models. Table 4 shows the 12 nested models and the comparative analysis of nested models and the theoretical model. 


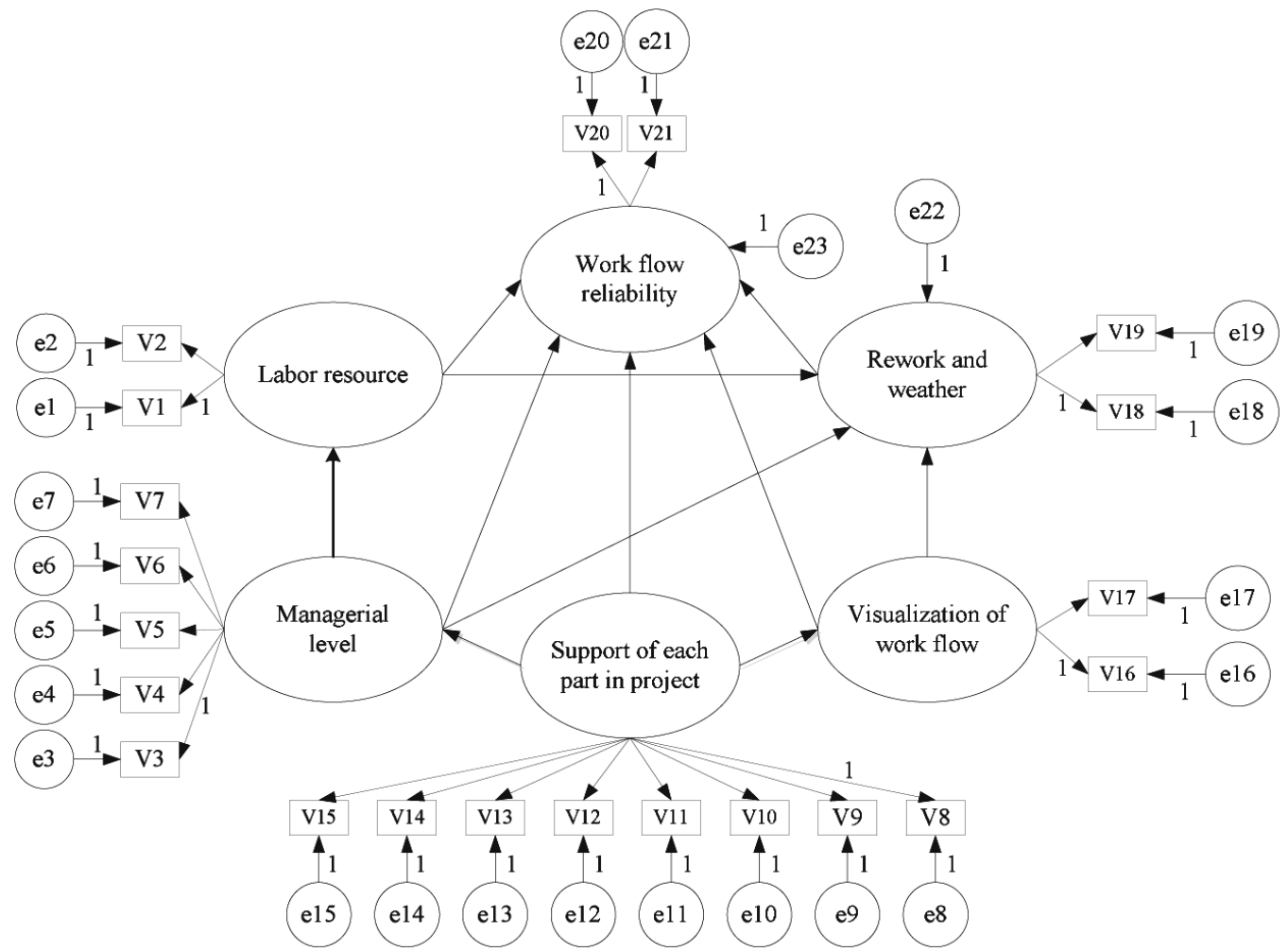

Fig. 2. Initial SEM of the interrelationship framework between work flow reliability and critical factors

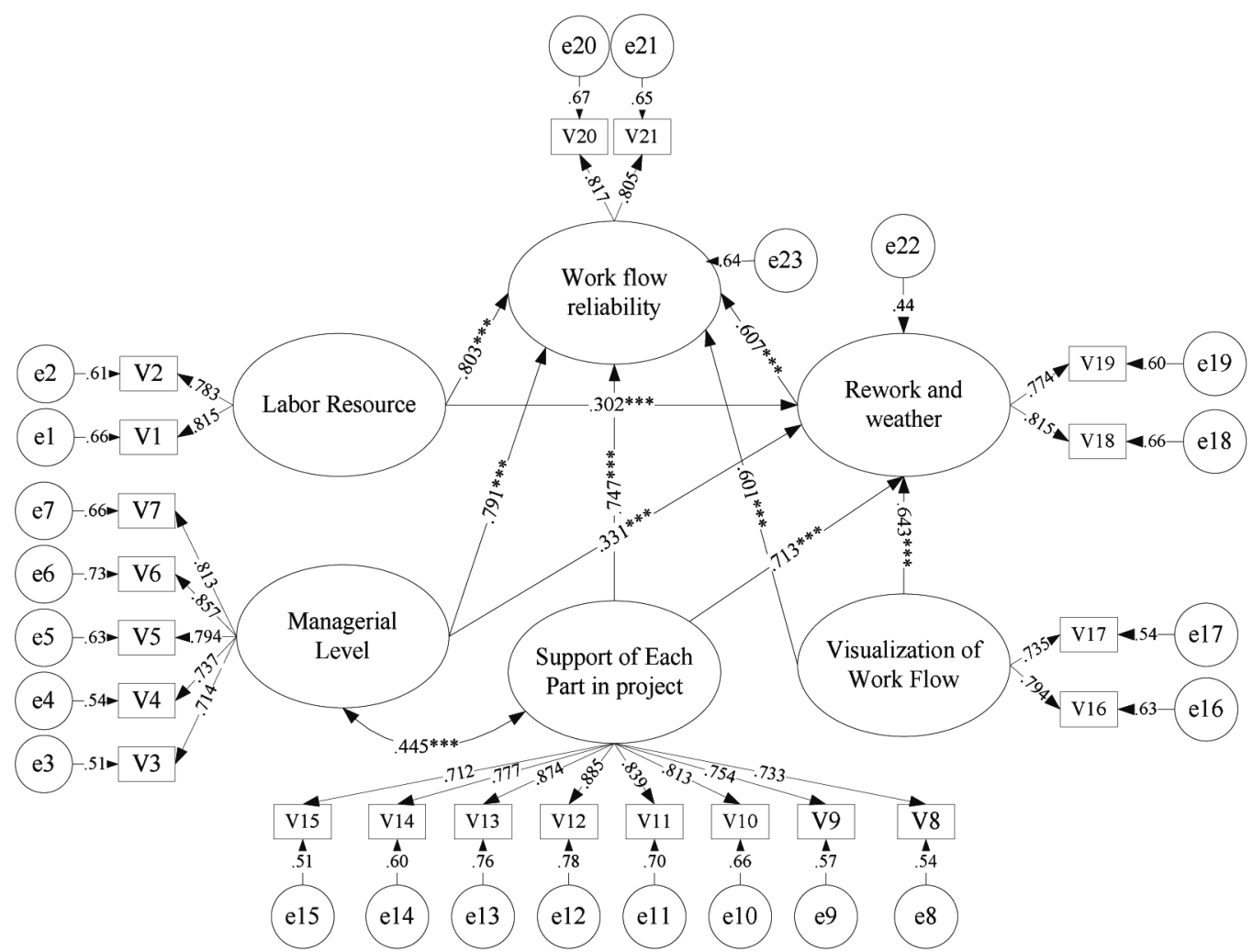

Fig. 3. Final SEM of the interrelationship framework between work flow reliability and critical factors Note: $* * *$ denote significance at $\mathrm{p}=0.000<0.05$. 
Table 3. Goodness of fit indices of the SEM framework

\begin{tabular}{l|c|c|c}
\hline \multicolumn{1}{c|}{ Evaluation index } & Goodness of fit & Final SEM & Acceptable level \\
\hline \multirow{2}{*}{ Absolute fit indices } & $\chi^{2} / d f$ & 1.843 & $\leq 2$ \\
& GFI & 0.94 & $>0.90$ \\
& RMSEA & 0.057 & $\leq 0.10$ \\
\hline \multirow{2}{*}{ Incremental fit indices } & NNFI & 0.96 & $>0.90$ \\
& CFI & 0.96 & $>0.90$ \\
\hline Parsimonious fit indices & PGFI & 0.677 & $>0.50$ \\
\hline
\end{tabular}

Table 4. Comparative analysis of nested models and theoretical models

\begin{tabular}{|c|c|c|c|c|c|c|c|c|}
\hline Models & Description & $x^{2}$ & $d f$ & $x^{2} / d f$ & GFI & RMSEA & CFI & $\Delta x^{2} / \Delta d f$ \\
\hline Theoretical model & & 318.839 & 173 & 1.843 & 0.940 & 0.057 & 0.960 & \\
\hline Nested model 1 & $\begin{array}{l}\text { Remove the } \mathrm{H} 1 \text { from } \\
\text { the theoretical model }\end{array}$ & 334.288 & 175 & 1.910 & 0.934 & 0.059 & 0.950 & $15.449 * * *(2)$ \\
\hline Nested model 2 & $\begin{array}{l}\text { Remove the } \mathrm{H} 2 \text { from } \\
\text { the theoretical model }\end{array}$ & 335.187 & 174 & 1.926 & 0.932 & 0.059 & 0.950 & $16.348 * * *(1)$ \\
\hline Nested model 3 & $\begin{array}{l}\text { Remove the } \mathrm{H} 3 \text { from } \\
\text { the theoretical model }\end{array}$ & 339.807 & 174 & 1.953 & 0.931 & 0.060 & 0.946 & $20.968 * * *(1)$ \\
\hline Nested model 4 & $\begin{array}{l}\text { Remove the } \mathrm{H} 4 \text { from } \\
\text { the theoretical model }\end{array}$ & 332.291 & 174 & 1.910 & 0.940 & 0.571 & 0.958 & $13.452 * * *(1)$ \\
\hline Nested model 5 & $\begin{array}{l}\text { Remove the } \mathrm{H} 5 \text { from } \\
\text { the theoretical model }\end{array}$ & 334.620 & 175 & 1.912 & 0.934 & 0.059 & 0.950 & $15.781 * * *(2)$ \\
\hline Nested model 6 & $\begin{array}{l}\text { Remove the H6 from } \\
\text { the theoretical model }\end{array}$ & 344.474 & 174 & 1.980 & 0.931 & 0.061 & 0.944 & $25.635 * * *(1)$ \\
\hline Nested model 7 & $\begin{array}{l}\text { Remove the } \mathrm{H} 7 \text { from } \\
\text { the theoretical model }\end{array}$ & 328.674 & 174 & 1.889 & 0.939 & 0.058 & 0.957 & $9.835^{* * *}(1)$ \\
\hline Nested model 8 & $\begin{array}{l}\text { Remove the } \mathrm{H} 8 \text { from } \\
\text { the theoretical model }\end{array}$ & 367.179 & 174 & 2.110 & 0.923 & 0.065 & 0.929 & $48.340 * * *(1)$ \\
\hline Nested model 9 & $\begin{array}{l}\text { Remove the } \mathrm{H} 9 \text { from } \\
\text { the theoretical model }\end{array}$ & 337.730 & 174 & 1.941 & 0.932 & 0.060 & 0.948 & $18.891 * * *(1)$ \\
\hline Nested model 10 & $\begin{array}{l}\text { Remove the H10 from } \\
\text { the theoretical model }\end{array}$ & 320.750 & 174 & 1.843 & 0.939 & 0.570 & 0.959 & $1.911(1)$ \\
\hline Nested model 11 & $\begin{array}{l}\text { Remove the H11 from } \\
\text { the theoretical model }\end{array}$ & 318.851 & 174 & 1.832 & 0.936 & 0.059 & 0.952 & $0.012(1)$ \\
\hline Nested model 12 & $\begin{array}{l}\text { Remove the H12from } \\
\text { the theoretical model }\end{array}$ & 321.612 & 174 & 1.848 & 0.940 & 0.057 & 0.958 & $2.773(1)$ \\
\hline
\end{tabular}

Note: $* * *$ denote significance at $\mathrm{p}=0.000<0.05$.

\section{Results and discussion}

The interrelationships among the critical factors of work flow are showed in Figure 3. According to Figure 3, the data verifies nine of the hypotheses whereas H10, H11, and H12 are proved to be unacceptable. The results are also supported by the nested model analysis. From Table 4, it is also noted that there is no significant difference comparing nested model 10 , nested model 11 and nested model 12 separately to theoretical model $\left(\Delta x^{2}(\Delta d f)=1.911 ; \Delta x^{2}(\Delta d f)=0.012 ; \Delta x^{2}(\Delta d f)=2.77\right)$. Also, each models' goodness of fit indices show no obvious variation. It indicates that managerial level has no direct influence on labor resource, support of each part has no direct influence on managerial level, and support of each part in project has no direct influence on visuali- zation of work flow. On the other hand, there exist significant differences between each nested model 1 to 9 and theoretical model, which is also supported by goodness of fit indices of these nine nested models. Therefore, H10, $\mathrm{H} 11$ and $\mathrm{H} 12$ are refused and the remaining nine hypotheses are verified. Thus, the validity of SEM application has been proved.

Labor resource has a positive influence on work flow reliability. It shows that the more loyal and stable the labor resource is, the more reliable work flow is. This result verifies past research by Thomas et al. $(2002,2003)$. Labor resource has a significant influence on work flow reliability and it is necessary to improve the labor flow reliability to improve the project performance. Besides, Lee et al. (2004) also found the impact of labor factors 
on work flow. Managerial level has a positive influence on work flow reliability. When the project management is good, the work flow will keep reliable. González et al. (2010) discovered that improving planning reliability would make the work flow reliable and improve the project performance. Wambeke et al. (2011) also found that work sequence affected the work flow reliability. Support of each part in project has a positive influence on work flow reliability. When the owners, suppliers, engineers, etc. do their best to make the project operate affluently, the work flow will stay at a more reliable level. According to Thomas et al. (2002, 2003), Tribelsky and Sacks (2010), information has a significant influence on work flow, appropriate information flow will reduce misunderstanding and improve the reliability of work flow. This study also verifies the influence that information has on work flow reliability. Besides, this study also verifies that equipment (Kim, J. K., Kim, K. 2010), materials supply (Choi, Minchin 2006), engineers and owners (Enshassi et al. 2010) have influences on work flow reliability. Visualization of work flow has a positive influence on work flow reliability. If the work process and information transmission keep clear and transparent, workers will understand the current work better and respond to problems more quickly. As a result, the work flow will keep reliable. This result conforms with past research that visualization of work flow would make it easily to control the work process according to the actual environment (Sacks et al. 2009). Less Rework and good weather have a positive influence on work flow reliability. It is obvious that less rework and good weather will make it possible to complete the work on time which will make the work flow more reliable.

Labor resource has a positive influence on less rework. This finding indicates that if labor resource is loyalty and stable, the task will be finished in a good level and reduce rework. To some extent, it can be explained that loyal labor resource will do their best to complete their work and reduce mistakes to reduce rework. Besides, stable labor resource means that workers reaching the standard satisfying the need of the actual work, which will make it easily to complete the task. Managerial level has a positive influence on less rework. When the project management is good, including appropriate amount of work, reliable planning, reasonable work, adequate prerequisite, and reasonable work sequence, rework will be less to some extent. It can be explained that appropriate amount of work will make the workers complete the work efficiently. Too much or too little work will make the workers inefficient. Besides, reliable planning, reasonable task and work sequence will reduce change of work plan, which will help workers finish their work quickly in a reliable way. Adequate prerequisite will provide a more convenient situation to complete the work. Visualization of work flow has a positive influence on less rework. It can be considered that when the work pro- cess and information transmission keep clear and transparent, workers will respond to the work and problems more rapidly, which will reduce the chance to make mistakes and reduce rework finally. Support of each part in project also has a positive influence on less rework. It can be explained that the construction work will be completed affluently if the owners, contractors, suppliers, engineers, etc. finish their work in a high quality.

Furthermore, this research also discovered other interrelationship among the latent variables. Managerial level and support of each part in project have positive correlations with each other. This suggests that a high level management will be followed by support of each part in project in a strong extent.

However, H10, H11, H12 are denied according to the model, which means that the interrelationships among these critical factors are not significant. Past research studied the influence of labor resource on work flow and other factors, which were also confirmed in this study. But study of factors affecting labor resource was seldom. The reason why managerial level has a direct influence on labor resource was denied maybe that managerial level, like reliable planning, reasonable work sequence, etc. is just external factors affecting labor resource. Labor resource, labor's loyalty and labor resource stability, is mainly affected by the internal factors. Managerial level in this research doesn't consist of internal factors. H11 was also denied according to the model. One reason is that these two factors involve different stages of a project. Managerial level in this research mainly involves planning management and work management. But support of each part in project mainly involves factors affecting actual construction process. H12 was also refused in the final model. Visualization of work flow mainly involves transparent information transmission and work process. Support of each part in project means that each part complete their own work well. Completing work well doesn't make information transmission and work process transparent. Besides, information transmission and work process are not enough transparent, which make it difficult to understand what transparent information transmission and work process can be and how they are affected by other factors. Another reason for denying H10, H11, H12 maybe these three hypotheses do not consist with the relationships underlying the collected data.

Besides, labor's loyalty has the most significant influence on labor resource. Adequate prerequisite has the most significant influence on managerial level. Owner's intervention has the most significant influence on support of each part in project. Transparent information and rapid transmission has the most significant influence on visualization. Those could help project managers understand which variables mainly affect critical factors and then take effective measures to manage these factors at an acceptable level. 


\section{Conclusions}

This paper identified critical factors of work flow reliability and developed interrelationships among these factors. Through factor analysis, five critical factors were identified including labor resource, managerial level, support of each part in project, visualization of work flow, and rework and weather. Then this paper put forward twelve hypotheses on the basis of the result of factor analysis and past research, to further explore how these factors correlate to each other and finally affect work flow reliability in lean construction. Structural equation modelling were adopted to testify the hypotheses. Finally, nine hypotheses were verified and three hypotheses were denied according to the final SEM. The authors then successfully conducted a nested model analysis to prove the validity of the SEM application. This study not only found out the critical factors of work flow reliability, but also presented a specific form of how these factors influence each other. This paper further more discovered other interrelationship among the critical factors of work flow reliability. Managerial level and support of each part in project have a positive correlation with each other.

The result of the SEM analysis shows that the path coefficients between each critical factors and work flow reliability vary from 0.601 to 0.803 . The best Path Coefficient was 0.803 , from labor resource to work flow reliability. It suggests that improving labor loyalty and labor resource stability would have maximal direct influence on work flow reliability. On the whole, the path coefficients lie in a high level, meaning that boosting these five critical factors would have a great impact on work flow reliability.

Critical factors identified in this paper make it easier to find the reason why the work flow is unreliable. Hence, this result will help project managers to find out the causes of unreliable work flow and take effective measures to reduce variability. Interrelationships among the critical factors discovered in this paper reveal the mechanism of how these factors influence each other. It can provide important implications for project managers to understand work flow reliability and control work flow more easily. For example, the model reveals that labor resource affects work flow reliability positively through the mediating effect of rework and weather. Therefore, it is necessary to improve labors' loyalty and stability to make labors complete the work in time with a high quality, which will reduce rework and improve work flow reliability.

Our research also suggests that studying the impact of all factors together is more insightful than in isolation for there are relationships among these factors. Hence, the development of integrated management of work flow practices seem to be a better application of lean thinking to control the variability in construction. Another significant conclusion of this research is that labor flow must be an important part of flow management in lean flows and should not be skimmed by lean construction managers since labor resource exerts such a major effects on work flow reliability. Except for the hypotheses, this paper discovered interrelationship that was not realized before. This finding will help draw new attention to interrelationships among the factors. As a result, this new finding will be verified in a new research in the future.

When identifying critical factors, rework and weather, two different types of factors, were classified into one category. As a result, it is not feasible to distinguish their respective effects on work flow reliability and relationships with other critical factors. Therefore, future research is required to develop a more accurate model to explain better interrelationships among the critical factors.

\section{Funding}

This work was supported by the National Natural Science Foundation of China [grant number 71272146] [grant number 71572126].

\section{References}

Bakker, A. B. 2008. The work-related flow inventory: construction and initial validation of the WOLF, Journal of Vocational Behavior 72(3): 400-414.

https://doi.org/10.1016/j.jvb.2007.11.007

Becker, T. C.; Shane, J. S.; Jalselskis, E. J. 2011. Comparative analysis of lean construction with design-build using a framework of contractual forms of agreement, Journal of Architectural Engineering 18(2): 187-191. https://doi.org/10.1061/(ASCE)AE.1943-5568.0000064

Chen, T. T.; Kao, C. H. 2010. A study of identifying success variables for construction partnering via SEM framework, Journal of Marine Science and Technology 18(5): 629636.

Chen, H.; Zeng, L.; Xie, J. Highway construction management information systems based on workflow, in 2008 International Conference on Intelligent Computation Technology and Automation, 20-22 October 2008, Hunan, 373-376. https://doi.org/10.1109/ICICTA.2008.464

Chen, W. T.; Chen, T.-T.; Lu, C. S.; Liu, S.-S. 2012a. Analyzing relationships among success variables of construction partnering using structural equation modeling: a case study of Taiwan's construction industry, Journal of Civil Engineering and Management 18(6): 783-794. https://doi.org/10.3846/13923730.2012.735062

Chen, Y. Q.; Zhang, Y. B.; Liu, J. Y.; Mo, P. 2012b. Interrelationships among critical success factors of construction projects based on the structural equation model, Journal of Management in Engineering 28(3): 243-251. https://doi.org/10.1061/(ASCE)ME.1943-5479.0000104

Cheung, S. O.; Chow, P. T. 2011. Withdrawal in construction project dispute negotiation, Journal of Construction Engineering and Management 137(12): 1071-1079. https://doi.org/10.1061/(ASCE)CO.1943-7862.0000388

Choi, J.; Minchin, R. E. 2006. Workflow management and productivity control for asphalt pavement operations, Canadian Journal of Civil Engineering 33(8): 1039-1049. https://doi.org/10.1139/106-055

Doloi, H. 2013. Cost overruns and failure in project management: Understanding the roles of key stakeholders in construction projects, Journal of Construction Engineering and Management 139(3): 267-279.

https://doi.org/10.1061/(ASCE)CO.1943-7862.0000621 
Enshassi, A.; Arain, F.; Al-Raee, S. 2010. Causes of variation orders in construction projects in the Gaza Strip, Journal of Civil Engineering and Management 16(4): 540-551. https://doi.org/10.3846/jcem.2010.60

González, V.; Alarcon, L. F.; Maturana, S.; Mundaca, F.; Bustamante, J. 2010. Improving planning reliability and project performance using the reliable commitment model, Journal of Construction Engineering and Management 136(10): 1129-1139. https://doi.org/10.1061/(ASCE)CO.1943-7862.0000215

Hon, C. K. H.; Chan, A. P. C.; Yam, M. C. H. 2013. Determining safety climate factors in the repair, maintenance, minor alteration, and addition sector of Hong Kong, Journal of Construction Engineering and Management 139(5): 519-528.

https://doi.org/10.1061/(ASCE)CO.1943-7862.0000588

Kim, K. J.; Kim, K. 2010. Case study on the evaluation of equipment flow at a construction site, Journal of Computing in Civil Engineering 24(6): 570-575. https://doi.org/10.1061/(ASCE)CP.1943-5487.0000051

Lee, H. S.; Yu, J. H.; Kim, S. K. 2004. Impact of labor factors on workflow, Journal of Construction Engineering and Management 130(6): 918-923. https://doi.org/10.1061/ (ASCE)0733-9364(2004)130:6(918)

Li, H.; Arditi, D.; Wang, Z. 2013. Factors that affect transaction costs in construction projects, Journal of Construction Engineering and Management 139(1): 60-68. https://doi.org/10.1061/(ASCE)CO.1943-7862.0000573

Liu, M.; Ballard, G.; Ibbs, W. 2011. Work flow variation and labor productivity: case study, Journal of Management in Engineering 27(4): 236-242. https://doi.org/10.1061/(ASCE)ME.1943-5479.0000056

Mitropoulos, P.; Nichita, T. 2010. Critical concerns of production control system on projects with labor constraints: lessons from a residential case study, Journal of Management in Engineering 26(3): 153-159. https://doi.org/10.1061/(ASCE)ME.1943-5479.0000015

Sacks, R.; Treckmann, M.; Rozenfeld, O. 2009. Visualization of work flow to support Lean construction, Journal of Construction Engineering and Management 135(12): 1307-1315.

https://doi.org/10.1061/(ASCE)CO.1943-7862.0000102
Salem, O.; Solomon, J.; Genaidy, A.; Minkarah, I. 2006. Lean construction: From theory to implementation, Journal of Management in Engineering 22(4): 168-175. https://doi.org/10.1061/(ASCE)0742-597X(2006)22:4(168)

Thomas, H. R. 2000. Schedule acceleration, work flow, and labor productivity, Journal of Construction Engineering and Management 126(4): 261-267.

https://doi.org/10.1061/(ASCE)0733-9364(2000)126:4(261)

Thomas, H. R.; Horman, M. J.; de Souza, U. E. L.; Zavřski, I. 2002. Reducing variability to improve performance as a Lean construction principle, Journal of Construction Engineering and Management 128(2): 144-154.

https://doi.org/10.1061/(ASCE)0733-9364(2002)128:2(144)

Thomas, H. R.; Horman, M. J.; Minchin, R. E.; Chen, D. 2003. Improving labor flow reliability for better productivity as Lean construction principle, Journal of Construction Engineering and Management 129(3): 251-261.

https://doi.org/10.1061/(ASCE)0733-9364(2003)129:3(251)

Tommelein, D.; Riley, D. R.; Howell, G. A. 1999. Parade Game: Impact of work flow variability on trade performance, Journal of Construction Engineering and Management 125(5): 304-310.

https://doi.org/10.1061/(ASCE)0733-9364(1999)125:5(304)

Tribelsky, E.; Sacks, R. 2010. Measuring information flow in the detailed design of construction projects, Research in Engineering Design 21(3): 189-206. https://doi.org/10.1007/s00163-009-0084-3

Wambeke, B. W.; Asce, M.; Hsiang, S. M.; Liu, M.; Asce, A. M. 2011. Causes of variation in construction project task starting times and duration, Journal of Construction Engineering and Management 137(9): 663-677. https://doi.org/10.1061/(ASCE)CO.1943-7862.0000342

Ye, K.; Li, B.; Shen, L. 2013. Key factors considered in compiling tender prices for China's public works projects, Journal of Management in Engineering 29(3): 206-215. https://doi.org/10.1061/(ASCE)ME.1943-5479.0000153

Zhang, P.; Ng, F. F. 2013. Explaining knowledge-sharing intention in construction teams in Hong Kong, Journal of Construction Engineering and Management 139(3): 280-293. https://doi.org/10.1061/(ASCE)CO.1943-7862.0000607

Lianying ZHANG. He is a professor of construction management in the College of Management and Economics at Tianjin University, China. His current research interests include project governance and knowledge management in construction projects and multi-objective optimization in construction management. Professor Zhang headed two projects for the National Natural Science Foundation of China, and is a recipient of the 2002 Best Prize in International Symposium on Construction Management and Real Estate.

Xi CHEN. She is a M.D student in the College of Management and Economics at Tianjin University, China. She holds an bachelor's degree in Southwest Jiaotong University. Her research focuses on lean construction and knowledge management.

Yongqing SUO. He is a M.D student in the College of Management and Economics at Tianjin University, China. His research focuses on lean construction and work flow. 